Article

\title{
Dual Anti-Malarial and GSK3 $\beta$-Mediated Cytokine-Modulating Activities of Quercetin Are Requisite of Its Potential as a Plant-Derived Therapeutic in Malaria
}

\author{
Amatul Hamizah Ali ${ }^{1}\left(\right.$, Suhaini Sudi ${ }^{2,3}, \mathrm{Ng}$ Shi-Jing ${ }^{2}$, Wan Rozianoor Mohd Hassan ${ }^{4}{ }^{\circledR}$, Rusliza Basir $^{5}$, \\ Hani Kartini Agustar ${ }^{6}$, Noor Embi ${ }^{2}$, Hasidah Mohd Sidek ${ }^{2}$ and Jalifah Latip ${ }^{1, *(D)}$ \\ 1 Department of Chemical Sciences, Faculty of Science and Technology, Universiti Kebangsaan Malaysia, \\ Bangi 43600, Selangor, Malaysia; amatulhamizahali@yahoo.com.my \\ 2 Department of Biological Sciences and Biotechnology, Faculty of Science and Technology, \\ Universiti Kebangsaan Malaysia, Bangi 43600, Selangor, Malaysia; suhainisudi@gmail.com (S.S.); \\ shijing9147@hotmail.com (N.S.-J.); noormb@ukm.edu.my (N.E.); hasidahms@gmail.com (H.M.S.) \\ 3 Department of Biomedical Sciences and Therapeutics, Faculty of Medicine and Health Sciences, \\ Universiti Malaysia Sabah, Kota Kinabalu 88400, Sabah, Malaysia \\ 4 School of Biological Sciences, Faculty of Applied Sciences, Universiti Teknologi MARA, \\ Shah Alam 40450, Selangor, Malaysia; rozianoor@uitm.edu.my \\ 5 Pharmacology Unit, Department of Human Anatomy, Faculty of Medicine and Health Sciences, \\ Universiti Putra Malaysia, Serdang 43400, Selangor, Malaysia; rusliza@upm.edu.my \\ check for \\ updates \\ Citation: Ali, A.H.; Sudi, S.; Shi-Jing, \\ N.; Hassan, W.R.M.; Basir, R.; Agustar, \\ 6 Department of Earth Sciences and Environment, Faculty of Science and Technology, \\ Universiti Kebangsaan Malaysia, Bangi 43600, Selangor, Malaysia; hani_ag@ukm.edu.my \\ * Correspondence: jalifah@ukm.edu.my
} H.K.; Embi, N.; Sidek, H.M.; Latip, J. Dual Anti-Malarial and GSK3 $\beta$ Mediated Cytokine-Modulating Activities of Quercetin Are Requisite of Its Potential as a Plant-Derived Therapeutic in Malaria. Pharmaceuticals 2021, 14, 248. https://doi.org/10.3390/ph14030248

Academic Editors:

Christophe Dardonville and Priyanka Panwar

Received: 20 January 2021

Accepted: 9 February 2021

Published: 9 March 2021

Publisher's Note: MDPI stays neutral with regard to jurisdictional claims in published maps and institutional affiliations.

Copyright: (C) 2021 by the authors Licensee MDPI, Basel, Switzerland. This article is an open access article distributed under the terms and conditions of the Creative Commons Attribution (CC BY) license (https:/ / creativecommons.org/licenses/by/ $4.0 /)$.

Abstract: Although death in malaria is attributed to cerebrovascular blockage and anaemia, overwhelming cytokine production can contribute to the severity of the disease. Therefore, mitigation of dysregulated inflammatory signalling may provide further benefit for malaria treatment. Quercetin $\left(3,3^{\prime}, 4^{\prime}, 5,7\right.$-pentahydroxyflavone) is known to inhibit glycogen synthase kinase-3 $\beta$ (GSK3 $\left.\beta\right)$, a potent regulator of both pro- and anti-inflammatory effects. Quercetin is therefore a potential therapeutic to modulate the imbalanced cytokine production during malarial infection. Anti-malarial effects of quercetin were evaluated in murine models of severe and cerebral malaria using Plasmodium berghei NK65 and ANKA strains, respectively. Western blotting and analysis of cytokines were carried out to determine the GSK3 $\beta$-mediated cytokine-modulating effects of quercetin in infected animals. Quercetin $(25 \mathrm{mg} / \mathrm{kg} \mathrm{BW})$ treatment in P. berghei NK65-infected animals resulted in $60.7 \pm 2.4 \%$ suppression of parasitaemia and significantly decreased serum levels of TNF- $\alpha$ and IFN- $\gamma$, whilst levels of IL-10 and IL-4 were elevated significantly. Western analysis revealed that pGSK3 $\beta$ (Ser9) increased 2.7-fold in the liver of quercetin-treated NK65-infected animals. Treatment of P. berghei ANKA-infected mice with quercetin $(15 \mathrm{mg} / \mathrm{kg}$ BW) increased (2.3-fold) pGSK3 $\beta$ (Ser9) in the brains of infected animals. Quercetin is a potential plant-derived therapeutic for malaria on the basis that it can elicit anti-malarial and GSK3 $\beta$-mediated cytokine-modulating effects.

Keywords: cytokine; GSK3 $\beta$; malaria; Plasmodium berghei; quercetin

\section{Introduction}

Aberrant cytokine production, or a "cytokine storm", can cause severe systemic inflammatory responses as well as tissue and organ damage in various viral, bacterial, and parasitic infections [1]. Drug-discovery efforts are now not only focusing on eliminating the causative agents of the disease but also on immunomodulatory activities in the host to mitigate the overwhelming cytokine production [2]. In the case of malaria, uncontrolled and excessive immune responses mounted by the host in an attempt to eliminate the parasite contribute significantly to the pathology of the disease [3]. Inflammatory cytokines 
such as TNF- $\alpha$ have important roles in the pathophysiology of cerebral malaria based on murine models of infection. For example, increased systemic TNF- $\alpha$ cytokine level and sequestration of parasitised erythrocytes in the brain can lead to coma and consequent death [4]. Excessive cytokines have also been associated with susceptibility to severe malarial anaemia by perturbing erythropoiesis. TNF- $\alpha$ inhibits major erythroid transcription factor GATA-1 expression and further inhibits erythroblast differentiation [5]. Modulation of immune-mediated inflammatory responses is, therefore, also significant in the therapeutic approach against malarial inflammation. Host signalling kinases activated by malarial infection represent attractive targets for anti-malarial intervention [6]. Many therapeutic effects of plant extracts and their bioactive compounds are also attributed to their immunomodulatory effects and influence on the host immune system [7]. Immunomodulation using plant-derived products is a plausible effective strategy in the development of adjunctive therapy, such as for the mitigation of the cytokine storm during pathogenic infections. Flavonoid constituents in various medicinal plants are known to possess a wide range of pharmacological activities, including anti-inflammatory effects. For example, the flavonol quercetin (3,3', $4^{\prime}, 5,7$-pentahydroxyflavone), an anti-oxidant and a common naturally-occurring phytochemical, exerts a marked effect on inflammation [8-11].

Quercetin inhibits the activation of nuclear factor- $\kappa \mathrm{B}(\mathrm{NF}-\kappa \mathrm{B})$, a transcription factor that regulates multiple aspects of innate and adaptive immune functions and thus serves as a pivotal mediator of inflammatory responses $[12,13]$. Quercetin is reported to significantly down-regulate TNF- $\alpha$, IL-1 $\beta$, and IL- 6 and attenuate the inflammatory response in LPS-induced RAW264.7 cells [14]. The current coronavirus (COVID-19) pandemic has created much attention and immense effort worldwide in the search for drugs (e.g., immunomodulators) that can reduce viral load and control inflammatory responses $[15,16]$. In this respect, Rudd [17] hypothesises that GSK3 $\beta$ inhibition is a plausible therapeutic approach against COVID-19, capitalising on the dual benefits of inhibiting viral replication while potentiating the immune response. For example, quercetin as an anti-viral agent $[18,19]$ is also known to exhibit in silico and in vitro inhibition of glycogen synthase kinase-3 $\beta$ (GSK3 $\beta$ ) [20,21]. Subsequently, Jung et al. [22] reported that flavonoids, including luteolin, apigenin, and quercetin, inhibit GSK3 $\beta$. Recently Friday et al. [23] also reported that quercetin and its analogues are inhibitors of GSK3 $\beta$ based on a study using pharmacophore modelling and molecular-docking techniques. This Ser/Thr kinase is a molecular hub linking numerous signalling pathways in the cell, including host-directed inflammatory responses. Thus, quercetin with its anti-inflammatory effects is a plausible therapeutic candidate for mitigating the cytokine storm [24]. It is noteworthy that the anti-parasitic activity of several naturally derived products has been attributed to the presence of quercetin or derived compounds [25]. There have been various reports on the anti-plasmodial activity of quercetin [26] and its analogues against clinical isolates of Plasmodium falciparum [27]. Recently, it was demonstrated that selected existing commercial flavonoids (including quercetin)-containing drugs for other diseases are active in malariainfected mice and in vitro against chloroquine-resistant $P$. falciparum [28]. It was suggested that the anti-oxidant capacity of the tested drugs could be responsible for the reduction of malaria severity. Treatment by combining flavonoids, known for their anti-oxidant and anti-inflammatory properties, with standard anti-malarial drugs protected mice infected with $P$. berghei [29]. Taken together, quercetin as an inhibitor of GSK3 $\beta$ may be useful to modulate immune responses during malarial infection.

Glycogen synthase kinase-3 (GSK3), initially described by Embi et al. [30] as a critical enzyme capable of phosphorylating, and consequently inhibiting glycogen synthase during insulin signalling, is now recognised as a point of convergence for host inflammatory response [31,32]. The pathophysiology of many diseases, including bipolar disorder, diabetes mellitus, Alzheimer's disease, inflammation, and cancer, involves dysregulation of this kinase [33]. In mammals, GSK3 is encoded by two highly related genes encoding GSK3 $\alpha$ and GSK3 $\beta$ isoforms of the enzyme, respectively. GSK3 is constitutively active under basal conditions; its regulation is attained mainly via the inhibitory serine-phosphorylation at 
Ser21 for GSK3 $\alpha$, and Ser9 for GSK3 $\beta$ [34]. Malfunction of GSK3 $\beta$ is implicated in the pathogenesis of several diseases [35]. GSK3 $\beta$ is also associated with the innate-immune response against pathogens [32], and thus GSK3 $\beta$ is a potential target for therapeutic intervention. During infections, GSK3 $\beta$ regulates the production of several pro-inflammatory cytokines while suppressing the production of anti-inflammatory cytokines [32]. Excessive production of pro-inflammatory cytokines during malarial infection can lead to liver and kidney injuries and consequent death [36,37].

Bioactive compounds with dual anti-malarial and anti-inflammatory properties not only may be beneficial in eliminating the plasmodial parasite, but also in modulating the cytokine response during malarial infection [2]. Based on the current understanding described above on the anti-inflammatory and GSK3 $\beta$-inhibitory activities of quercetin, we propose to evaluate whether the anti-malarial activity of quercetin in a mouse model of malarial infection also involves modulation of inflammatory cytokine response. Findings from the present study may give further insight into whether this flavonol is a plausible candidate in the development of adjunctive therapeutics to mitigate the cytokine storm during malarial infection.

\section{Results}

\subsection{Quercetin Exhibits Moderate Anti-Plasmodial Activity}

In vitro anti-plasmodial assessment of quercetin showed an $\mathrm{IC}_{50}$ value of $19.31 \pm 1.26 \mu \mathrm{M}$ against the chloroquine-sensitive strain of P. falciparum 3D7. This value is considered as moderate anti-plasmodial activity based on classification by Dolabela et al. [38]. In comparison, chloroquine (CQ), the reference anti-malarial drug showed potent anti-plasmodial effect $\left(\mathrm{IC}_{50}=0.0023 \pm 0.0001 \mu \mathrm{M}\right)$. For cytotoxic evaluation, quercetin showed minimal toxicity towards mammalian Chang liver cells $\left(\mathrm{IC}_{50}=868.22 \pm 3.81 \mu \mathrm{M}\right)$. A selectivity index (SI) value exceeding 10 for quercetin $(\mathrm{SI}=44.9)$ suggests that this compound is selective for the parasite and thus a plausible anti-plasmodial compound.

\subsection{Quercetin Displayed No Adverse Effect in Non-Infected Mice}

All non-infected mice showed $100 \%$ survivability until day 30 after being injected (i.p.) with $2.5,5,10,15,25$, and $50 \mathrm{mg} / \mathrm{kg}$ BW quercetin. During the 30-day observation period, most non-infected animals did not show any adverse behavioural and physical changes as compared to the control group. Mice from the $50 \mathrm{mg} / \mathrm{kg}$ BW group however displayed mild toxicity (lethargy and reduction in locomotor activities). This finding indicates that doses of quercetin of up to $25 \mathrm{mg} / \mathrm{kg}$ BW tested here may be further employed for the subsequent four-day suppressive test.

\subsection{Quercetin Suppressed Parasitaemia Development and Prolonged Median Survival Time in P. berghei NK65- and ANKA-Infected Animals}

$P$. berghei NK65-infected mice treated with quercetin at $25 \mathrm{mg} / \mathrm{kg}$ BW displayed the highest chemo-suppressive activities, $60.7 \pm 2.4 \%(p<0.05)$ (Table 1; Figure 1). Quercetin was able to exhibit dose-dependent anti-malarial activity from 2.5 to $25 \mathrm{mg} / \mathrm{kg}$ BW. Suppressive activity was slightly reduced at $50 \mathrm{mg} / \mathrm{kg}$ BW. The reduction of activity might be due to quercetin-caused mild toxicity at $50 \mathrm{mg} / \mathrm{kg}$ BW. Detoxification mechanisms in experimental animals to excrete the drug from the animals may result in reduction of the drug activity [39]. However, median survival time for doses of 25 and $50 \mathrm{mg} / \mathrm{kg}$ BW were the highest (17 days) as compared to controls without treatment (13 days). For P. berghei ANKA infection, treatment with quercetin $(15 \mathrm{mg} / \mathrm{kg} \mathrm{BW})$ in mice resulted in the highest chemo-suppressive effects of $36.10 \%(p<0.05)$ compared to the non-treated infected group (Table 1; Figure 1). Chemo-suppressive effects from all doses used in the study that did not exceed $50 \%$ may be due to the pathogenicity and severity of the ANKA strain commonly known as a cerebral parasite, which usually targets the brains of the infected animals at the early stage of the infection [40,41]. However, improvement of the median survival time can be significantly observed in mice treated with quercetin $15 \mathrm{mg} / \mathrm{kg} B W$ 
(10 days) as compared to controls without treatment (7 days). The CQ-treated group for NK65 and ANKA infections exhibited the highest chemo-suppressive activities $(96.0 \%$ and 94.3\% respectively) compared to other treatment groups, consistent with its function as an established anti-malarial reference drug. As for $\mathrm{LiCl}$ (GSK3 inhibitor reference compound), chemo-suppressive values were significant for both NK65 and ANKA infections (69.4\% and $85.2 \%$, respectively).

Table 1. Quercetin-suppressive activity in P. berghei NK65 and ANKA-infected mice.

\begin{tabular}{|c|c|c|c|c|c|c|}
\hline \multirow{2}{*}{$\begin{array}{l}\text { P. berghei strain } \\
\text { Compound/Drugs }\end{array}$} & \multicolumn{3}{|c|}{ P. berghei NK65 } & \multicolumn{3}{|c|}{ P. berghei ANKA } \\
\hline & $\begin{array}{c}\text { Dosage }(\mathrm{mg} / \mathrm{kg} \\
\text { BW) }\end{array}$ & $\begin{array}{l}\text { Parasitaemia } \\
\text { Suppression on } \\
\text { Day } 4(\%)\end{array}$ & $\begin{array}{l}\text { Median Survival } \\
\text { Time (Days) }\end{array}$ & $\begin{array}{c}\text { Dosage (mg/kg } \\
\text { BW) }\end{array}$ & $\begin{array}{l}\text { Parasitaemia } \\
\text { Suppression on } \\
\text { Day } 4(\%)\end{array}$ & $\begin{array}{l}\text { Median Survival } \\
\text { Time (Days) }\end{array}$ \\
\hline \multirow{5}{*}{ Quercetin } & 2.5 & $46.9 \pm 3.5^{\mathrm{a}}$ & $9^{b}$ & 15 & $36.1 \pm 5.7^{\mathrm{a}}$ & $10^{\mathrm{a}}$ \\
\hline & 5 & $51.1 \pm 5.7^{\mathrm{a}}$ & 13 & 25 & $24.9 \pm 3.8^{\mathrm{a}, \mathrm{b}}$ & $9^{b}$ \\
\hline & 10 & $53.5 \pm 4.3^{\mathrm{a}}$ & 14 & 50 & $24.3 \pm 1.8^{\mathrm{a}, \mathrm{b}}$ & $9^{b}$ \\
\hline & 25 & $60.7 \pm 2.4^{\mathrm{a}}$ & $17^{\mathrm{a}}$ & & & \\
\hline & 50 & $49.3 \pm 3.6^{a}$ & $17^{\mathrm{a}}$ & & & \\
\hline $\begin{array}{l}\text { CQ (Anti-malarial } \\
\text { reference drug) }\end{array}$ & 10 & $96.0 \pm 1.1^{\mathrm{a}}$ & $>30^{a}$ & 10 & $94.3 \pm 1.8^{\mathrm{a}}$ & $>30^{a}$ \\
\hline $\begin{array}{l}\mathrm{LiCl} \text { (GSK3 } \\
\text { inhibitor } \\
\text { reference) }\end{array}$ & 100 & $69.4 \pm 3.2$ & $15^{\mathrm{a}}$ & 100 & $85.2 \pm 0.9^{a}$ & $10^{\mathrm{a}}$ \\
\hline $\begin{array}{l}0.85 \%(w / v) \mathrm{NaCl} \\
\text { (Negative control) }\end{array}$ & $0.2 \mathrm{~mL}$ & - & 13 & $0.2 \mathrm{~mL}$ & - & 7 \\
\hline
\end{tabular}

Data represent mean \pm SD for parasitaemia suppression and median survival time $(n=7) .{ }^{\text {a }}$ represents values significantly different from negative control $(p<0.05),{ }^{\mathrm{b}}$ represents value which significantly different from CQ $(p<0.05)$.

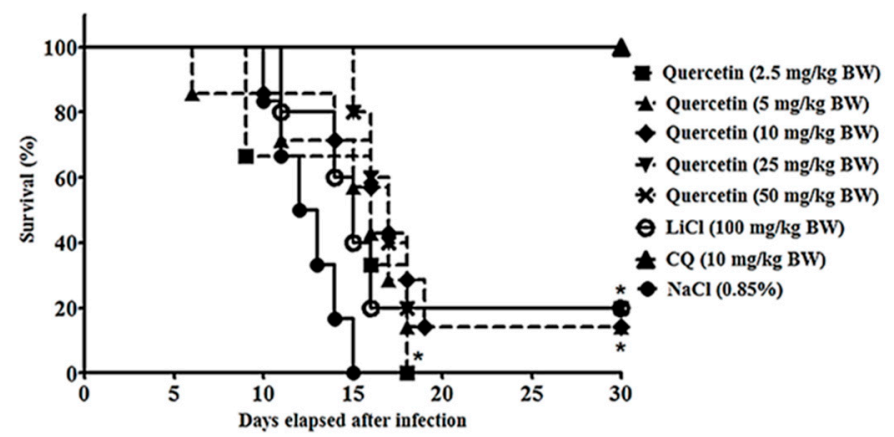

(a)

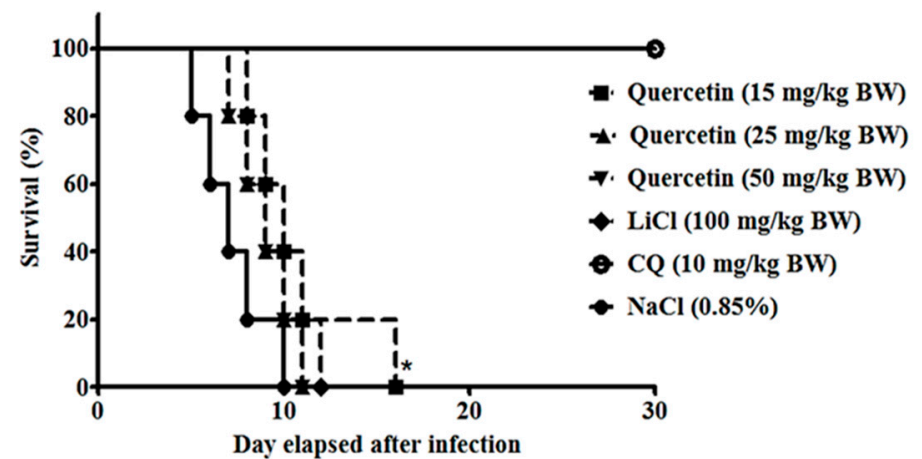

(b)

Figure 1. Representative Kaplan-Meier survival curve during the four-day suppressive test in (a) P. berghei NK65-infected mice and (b) ANKA-infected mice with and without quercetin. Figures show survival data for NaCl-treated (negative control) $(n=7)$, quercetin-treated $(\mathrm{n}=7)$, CQ-treated $(n=7)$, and LiCl-treated $(n=7)$ mice. Significant differences between tested and control groups were determined at $p<0.05\left(^{*}\right)$.

\subsection{Quercetin Resulted in Increased GSK3 $\beta$ (Ser9) Phosphorylation in the Liver of P. berghei NK65-Infected Mice}

Western-blot analysis from non-infected groups showed the presence of GSK3 $\beta$ and pSer9 GSK3 $\beta$ in liver samples, as seen from the immunoreactive-GSK3 and -pSer9 GSK3 protein bands. The intensities of the immunoreactive bands of GSK3 $\beta$ were uniform, indicating that the total GSK3 $\beta$ protein levels were the same in treated and control groups. Animals treated with quercetin and $\mathrm{LiCl}$ each showed significant increases in pSer9 GSK3 $\beta$ with an increment of 2.3- and 2.7-fold, respectively, compared to the control group. The intensities of immunoreactive bands for pSer9 GSK3 $\beta$ were higher for quercetin- and LiCltreated groups as compared to control groups. Meanwhile, immunoreactive-pSer9 GSK3 $\beta$ 
protein bands for CQ showed low intensities as compared to quercetin- and LiCl-treated groups (Figure 2).

\section{(a) Non-infected group}

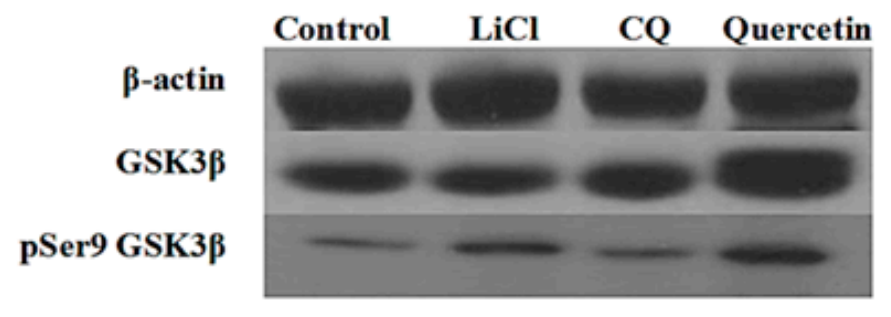

(i)

(b) Infected group

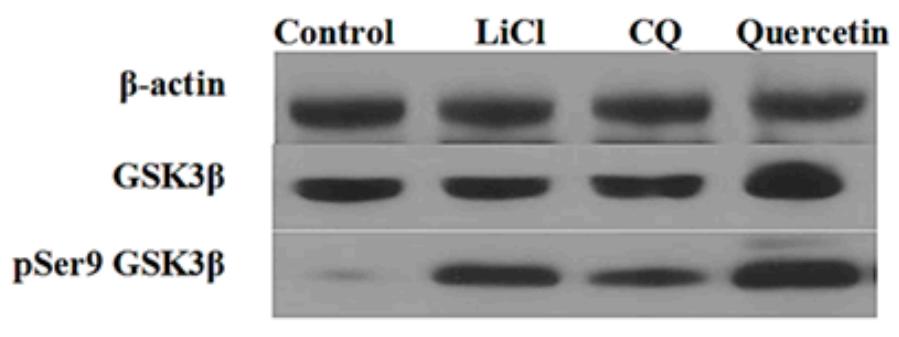

(i)

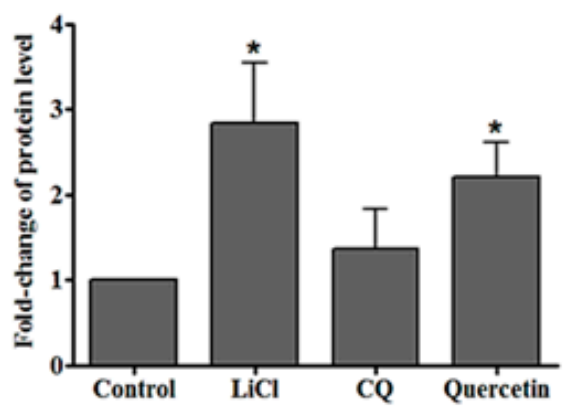

(ii)

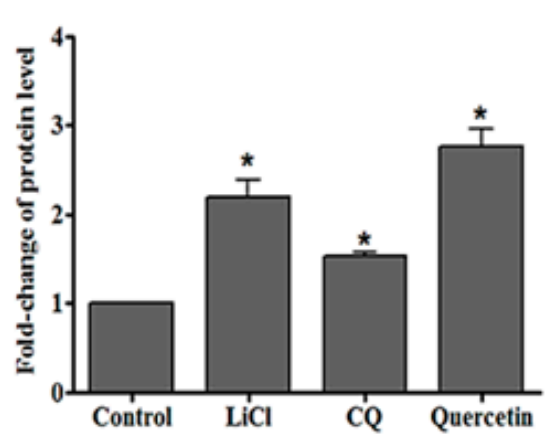

(ii)

Figure 2. (a) (i) Intensity of immunoreactive bands for pSer9 GSK3 $\beta$ and GSK3 $\beta$ (ii) Fold change of phosphorylated protein levels in liver of non-infected mice; (b) (i) Intensity of immunoreactive bands for pSer9 GSK3 $\beta$ and GSK3 $\beta$ (ii) Fold change of phosphorylated protein levels in liver of mice infected with P. berghei NK65 treated with $\mathrm{LiCl}$, CQ, or quercetin for four days. Total GSK3 $\beta$ protein expression levels were normalised to $\beta$-actin, and pGSK3 $\beta$ was normalised to total GSK $3 \beta$ protein level. Densitometric measurements are illustrated as mean (fold) \pm SD of corresponding measurements in non-treated controls. Significant differences between test and control groups were measured at $p<0.05\left(^{*}\right)$.

As for P. berghei NK65-infected groups, western analysis of liver samples showed that GSK3 $\beta$ and pSer9 GSK3 $\beta$ were present as immunoreactive-GSK3 $\beta$ and -pSer9 GSK3 $\beta$ protein bands were detected. Uniform intensities in immunoreactive-GSK3 $\beta$ protein bands indicate the same level of total GSK3 $\beta$ protein in both treated and control groups. Figure 2 shows that there was a significant fold-change increase of pSer9 GSK3 $\beta$ protein in the liver samples of infected mice. P. berghei NK65-infected mice treated with quercetin and $\mathrm{LiCl}$ each showed significant increases in the fold change of pSer9 GSK3 3 (2.7- and 2.2-fold increment, respectively, compared to non-treated controls).

\subsection{Quercetin Resulted in Increased GSK3 3 (Ser9) Phosphorylation in Brains of P. berghei ANKA-Infected Mice}

Western-blot analysis for non-infected animals showed the presence of GSK3 $\beta$ and pSer9 GSK3 $\beta$ in non-infected brain samples, as seen from the immunoreactive-GSK3 and -pSer9 GSK3 protein bands. The intensities of the immunoreactive bands of GSK3 $\beta$ were similar, indicating that the total GSK3 $\beta$ protein levels were the same in the treatment group and control group. The intensities of immunoreactive bands for pSer9 GSK3 $\beta$ were higher for quercetin- and LiCl-treated groups. Animals treated with quercetin and $\mathrm{LiCl}$ each showed significant increases in pSer9 GSK3 $\beta$ with an increment of 1.2-fold for both treatments compared to the control group. Meanwhile, immunoreactive-pSer9 GSK3 $\beta$ 
protein bands for CQ have lower intensities as compared to quercetin- and LiCl-treated groups (Figure 3).

\section{(a) Non-infected group}

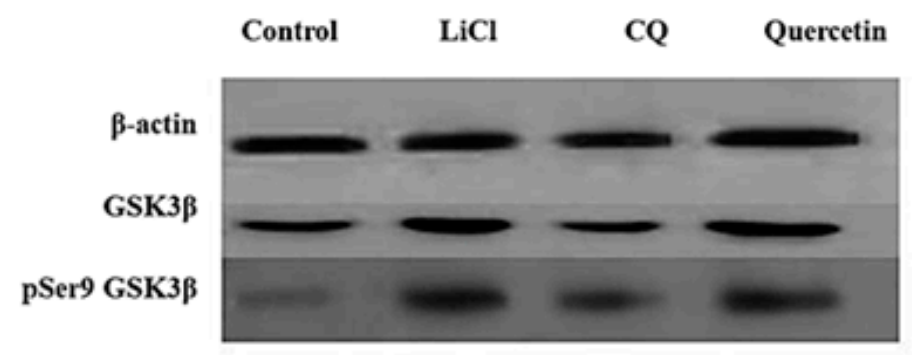

(i)

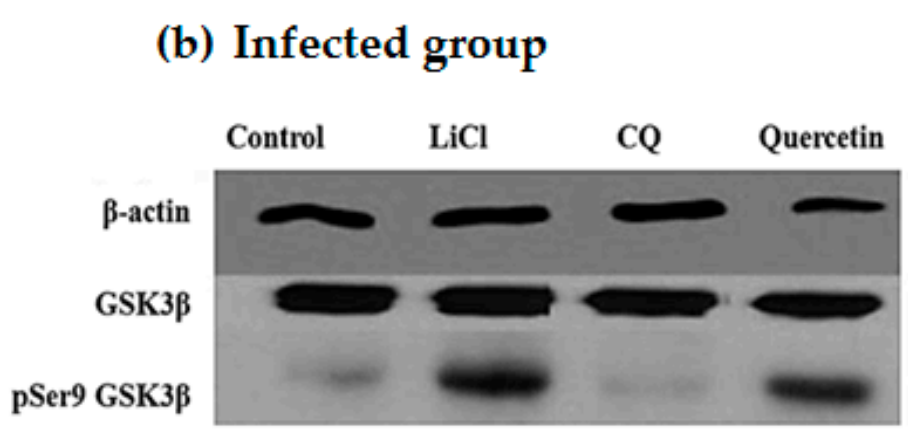

(i)

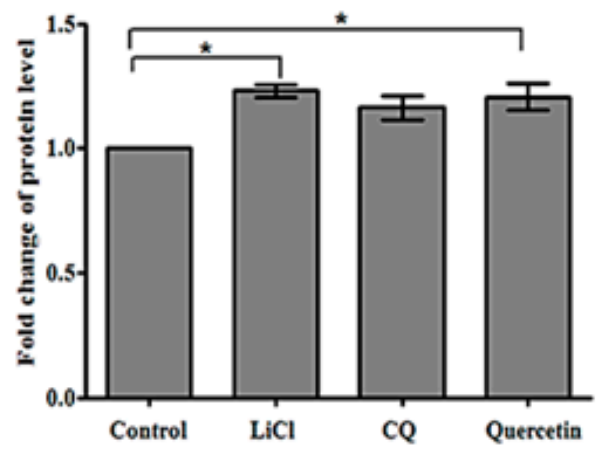

(ii)

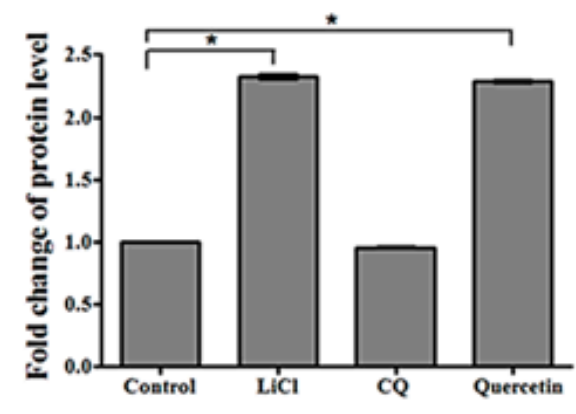

(ii)

Figure 3. (a) (i) Intensity of immunoreactive bands for pSer9 GSK $3 \beta$ and GSK3 $\beta$ (ii) Fold change of phosphorylated protein levels in the brain of non-infected mice; (b) (i) Intensity of immunoreactive band for pSer9 GSK3 $\beta$ and GSK3 $\beta$ (ii) Fold change of phosphorylated protein levels in mice infected with P. berghei ANKA treated with $\mathrm{LiCl}, \mathrm{CQ}$, or quercetin for four days. Total GSK3 $\beta$ protein expression levels were normalised to $\beta$-actin, and pGSK3 $\beta$ was normalised to total GSK3 $\beta$ protein level. Densitometric measurements are illustrated as mean (fold) \pm SD of corresponding measurements in non-treated controls. Significant differences between control and test groups were measured at $p<0.05\left(^{*}\right)$.

As for P. berghei ANKA-infected groups, western analysis of brain samples showed that GSK3 $\beta$ and pSer9 GSK3 $\beta$ were present as immunoreactive-GSK3 $\beta$ and -pSer9 GSK3 $\beta$ protein bands. Uniform intensities in immunoreactive-GSK3 $\beta$ protein bands indicate the same level of total GSK3 $\beta$ protein in both treated and control groups. Figure 3 shows a significant fold increase of pSer9 GSK3 $\beta$ protein in the brain sample of infected mice. $P$. berghei ANKA-infected mice treated with quercetin and $\mathrm{LiCl}$ each showed a significant increase in the fold change of pSer9 GSK3 $\beta$ with a 2.3-fold increment for both treatments compared to non-treated controls.

\subsection{Quercetin Modulated Pro- and Anti-Inflammatory Cytokine Levels in P. berghei NK65-Infected Animals}

Inflammatory cytokine measurements indicated that there were increases in both pro- and anti-inflammatory cytokine levels on day four after P. berghei NK65 infection. Upon parasite infection, levels of pro- and anti-inflammatory cytokines TNF- $\alpha$, IFN- $\gamma$, IL-10, and IL-4 were increased by 7.0, 10.0, 14.0, and 1.5 times, respectively, in the systemic blood circulation of infected mice (Figure 4). On day four post-infection, the levels of pro-inflammatory cytokines TNF- $\alpha$ and IFN- $\gamma$ were decreased to 6.6 and 2.5 times that 
observed in controls respectively while the levels of anti-inflammatory cytokine IL-10 and IL-4 were increased (by 2.1 and 5.7 times) upon quercetin treatment (Figure 4). As for mice-treated with LiCl, levels of TNF- $\alpha$ and IFN- $\gamma$ decreased to 3.1 and 1.6 times that in controls, respectively. Level of IL-10 and IL-4 increased to 1.2 and 2.4 times that in controls, respectively. For CQ treatment, levels of pro-inflammatory cytokines TNF- $\alpha$, IFN- $\gamma$, IL-10 and IL-4 were also decreased significantly after infection (to 12.0, 25.0, 9.0, and 1.5 times that in controls, respectively). CQ has anti-parasitic and anti-inflammatory properties, which can directly inhibit the growth of parasite at the early stage of infection and exert a direct effect on the host immune system [42,43].

A

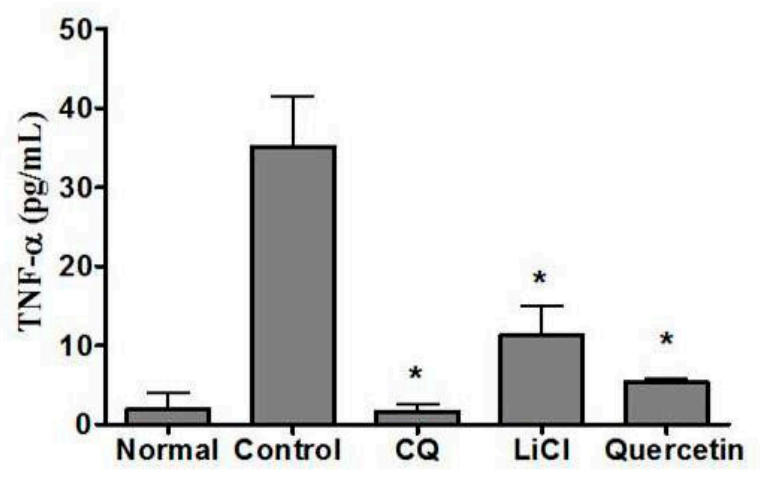

C

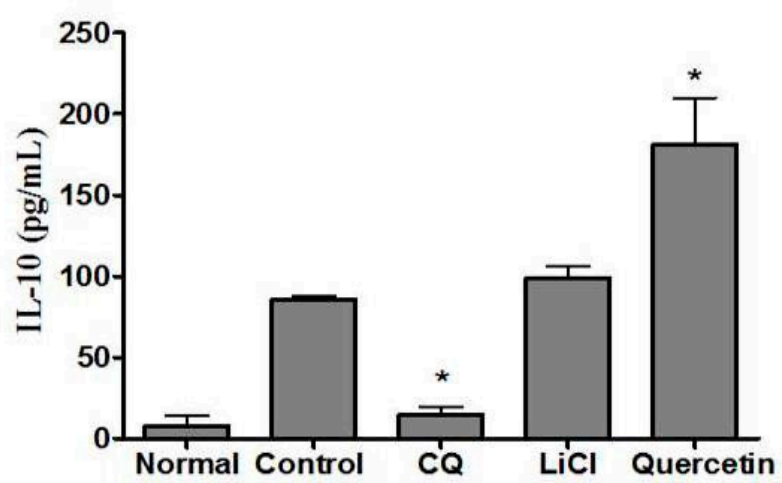

B

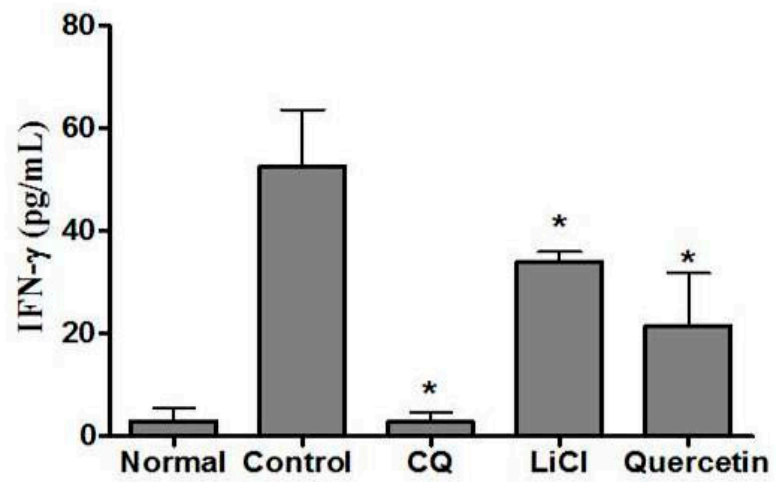

D

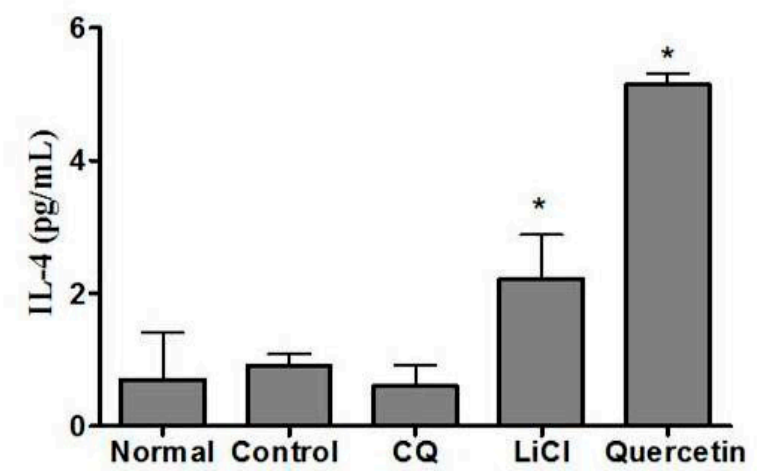

Figure 4. At day 4, post-infection of $P$. berghei NK65, pro-inflammatory cytokine (A) TNF- $\alpha$, (B) IFN- $\gamma$ and anti-inflammatory cytokines (C) IL-10 and (D) IL-4 levels in serum of mice administered with CQ, LiCl, or quercetin. Data represent mean \pm SD of normal (non-infected), control (infected), and $\mathrm{CQ} / \mathrm{LiCl}$ /quercetin-treated infected mice $(n=7)$. Significant differences between control (infected) and treatment groups were determined at $p<0.05{ }^{*}$ ).

\section{Discussion}

Findings from our in vitro studies showed that quercetin exhibited moderate antiplasmodial activity with a high selectivity index. This observation that quercetin exhibits in vitro anti-plasmodial activity corroborates previous reports by other investigators [28]. Another study [44] showed that aminoalkylated-quercetin analogues exhibited strong anti-malarial activities with $\mathrm{IC}_{50}$ values within the nanomolar to low micromolar range against $P$. falciparum W2, D6, and C235. Dysregulation of GSK3 $\beta$ during infection can result in overwhelming production of pro-inflammatory cytokines [32]. Thus, inhibitors of GSK3 not only can potentially serve as anti-malarial agents but also as cytokine modulators [45]. During malarial infection, excessive pro-inflammatory response contributes to the pathophysiology of the disease [3]. A feasible therapeutic approach in host-directed therapy is to mitigate the overwhelming cytokine response. GSK3 inhibitors as therapeutics 
potentially afford dual benefits [17], thus suitable to be explored in the treatment of malaria, i.e., inhibiting parasite growth and concomitantly modulating cytokine balance.

Findings from the present in vivo studies demonstrated that quercetin has antimalarial activities as well as a cytokine-modulating effect. Our study revealed that following quercetin treatment, there is significant reduction in the levels of pro-inflammatory cytokines; TNF- $\alpha$ and IFN- $\gamma$ and increased levels of anti-inflammatory cytokines; and IL-10 and IL-4 evidence of quercetin-modulated pro- and anti-inflammatory cytokine levels in $P$. berghei NK65-infected animals. Although the anti-malarial effect of quercetin has been documented previously by other investigators, the present study represents the first report of the dual anti-malarial and cytokine-modulating activities of quercetin. The antimalarial effect of quercetin demonstrated here is only moderately potent compared to CQ; nevertheless, it is envisaged that the dual anti-malarial and cytokine-modulating effects of quercetin render it a potential adjunctive therapeutic. Based on its anti-inflammatory and anti-plasmodial activity for malaria, quercetin, when combined with current antimalarials, may be useful as a new and more effective preventive and therapeutic agent against malaria, albeit subject to a clinical trial. Quercetin acted not only in suppressing the intra-erythrocytic stage of $P$. berghei NK65 but also in improving animal survivability. It is tempting to speculate that the increase in mean survival time observed in the present study is at least in part attributed to quercetin mitigating the cytokine storm.

In this study, based on the western analysis, we have also demonstrated that treatment with quercetin resulted in increased pGSK3 $\beta$ (Ser9) and thus inhibition of GSK3 $\beta$ activity in the liver of quercetin-treated NK65-infected animals. Since GSK3 $\beta$ is involved in the innate and adaptive immune response through the regulation of cytokine production [32], higher GSK3 $\beta$ in the liver of untreated NK65-infected mice may be associated with increased proinflammatory cytokine production during inflammation upon parasite infection. Quercetin treatment in P. berghei NK65-infected animals resulted in significant reduction in the levels of pro-inflammatory cytokines; TNF- $\alpha$ and IFN- $\gamma$ and increased levels of anti-inflammatory cytokines; and IL-10 and IL-4. This balancing in the production of cytokines may be a consequence of the inhibitory effect of quercetin on GSK3 $\beta$, a kinase that plays a pivotal role in mediating inflammation [46]. These findings suggest that quercetin modulates the level of inflammatory cytokines through phosphorylation and consequent inhibition of GSK3 $\beta$ in the liver of NK65-infected animals. Besides, GSK3 $\beta$ inhibition is known to drive the maturation and function of natural-killer (NK) cells [47] and thus can contribute to parasite clearance. As demonstrated in this study, quercetin treatment displayed chemosuppressive effects in P. berghei-infected animals. This study is not the first report on a plant-derived compound that can inhibit host GSK3 $\beta$ in malaria-infected animals. We have previously reported that curcumin, an active anti-inflammatory agent, inhibited GSK3 $\beta$ in the liver of NK65-infected mice. Also, in our laboratory, we have previously shown that the anti-malarial effects of kaempferol (also a flavone and structurally very similar to quercetin) involved cytokine modulation mediated through inhibition of host GSK3 $\beta$ [48]. Subsequently, Somsak et al. [49] demonstrated that combination treatment using CQ and kaempferol presented significant anti-malarial effects. Recently, Ounjaijean et al. [50] reported that a combination of kaempferol and artemisinin exerted potent anti-malarial activity with a synergistic effect against PbANKA-infected mice and suggested this effect could be attributed to the anti-oxidant and anti-cancer activities of kaempferol. On the other hand, it is tempting to speculate that the anti-inflammatory and GSK3 $\beta$-inhibitory properties of kaempferol possibly also contribute to the above reported anti-malarial effects. Thus, flavonoids exhibiting GSK3 $\beta$-inhibitory properties can be exploited for the development of therapies for malaria.

Our western-blot analysis also revealed that pSer9 GSK3 $\beta$ protein level is higher in the brain of $P$. berghei ANKA-infected mice treated with quercetin as compared to the control group. Our results showed that quercetin treatment was able to inhibit the GSK3 $\beta$ in the brain of ANKA-infected mice. Quercetin has also been reported to have the capability to infiltrate the blood-brain barrier (BBB) in mice, which allows it to be an 
effective neuroprotective agent $[51,52]$. The capability of this flavonoid penetrating the BBB and inhibiting GSK3 $\beta$ in the brain of ANKA-infected mice may be one of the reasons that this compound prolonged animal survivability as demonstrated in our present study. High levels of pGSK3 $\beta$ (pSer9 GSK3 $\beta$ ) in LiCl-treated infected mice were also observed in NK65-infected animals, indicating that GSK3 $\beta$ is inhibited. LiCl, a GSK3 inhibitor used as a reference inhibitor in this experiment, inhibited GSK3 $\beta$ and reduced the production of pro-inflammatory cytokines during infection. $\mathrm{LiCl}$ is reported to directly inhibit GSK3 $\beta$ through Akt activation via the PI3K signalling pathway [53,54]. LiCl has been shown to cause direct inhibition of GSK3 through GSK3 $N$-terminal phosphorylation as observed from rapid Ser9 phosphorylation in 293T, Neuro2A, and NIH3T3 cells [55]. The fold change of pSer9 GSK3 $\beta$ in quercetin-treated mice is similar to that of LiCl-treated mice, suggesting that in vivo, quercetin has a GSK3 $\beta$-inhibitory effect that is comparable to $\mathrm{LiCl}$. Our previous study showed that $\mathrm{LiCl}$ suppressed the development of parasitaemia in P. berghei NK65-infected animals [56]. A subsequent study by Dai et al. [57] showed that $\mathrm{LiCl}$ was able to modulate the levels of pro- and anti-inflammatory cytokines in the brain of ANKA-infected mice through GSK3 $\beta$ inhibition.

Findings from our study revealed that quercetin and chloroquine treatments each decreased the levels of pro-inflammatory cytokines TNF- $\alpha$ and IFN- $\gamma$ significantly. As for the anti-inflammatory cytokines, IL-4 and IL-10, only quercetin (and not chloroquine) treatment was observed to increase the levels, therefore suggesting that quercetin and chloroquine may be working via different mechanisms in affecting the (anti-inflammatory) cytokine levels. The cytokine-modulatory effect of quercetin observed here renders it different from conventional anti-malarial agents, which in most cases, only exhibit antiparasitic activity. Recently however, chloroquine was shown to exhibit not only antiparasitic activity but also anti-inflammatory properties and thus may directly affect the host immune system [42]. The mechanism of host-mediated response due to chloroquine is however still not fully understood [58]. Immune mechanisms associated with chloroquine treatment can be different between human and animal infections. For example, in a controlled human-malaria study, IFNs were shown to regulate immune response by promoting IL-10 to suppress inflammatory cytokines; additionally, parasite-specific IL-10 production was observed in P. falciparum patients in the field following chemoprophylaxis with chloroquine or artemisinin [59].

Furthermore, $\mathrm{LiCl}$ treatment restored long-term neurocognitive function in experimental cerebral malaria suggesting that the anti-malarial effect is attributed to the dysregulation of GSK3 $\beta$ [57]. The most serious and increasingly lethal neurological complication of infection with P. falciparum is cerebral malaria, responsible for over two million deaths annually. In terms of minimizing neurological and cognitive impairments, the current treatment is insufficient [60]. The pathophysiology of cerebral malaria is complicated. Nevertheless, GSK3 may be one of the plausible targets to be exploited in adjunctive therapy to overcome neurological deficits. Recently, Worthen et al. [61] demonstrated that anti-inflammatory IL-10 administration rescues depression-associated learning and memory deficits in mice. As mentioned earlier, Dai et al. [57] reported that $\mathrm{LiCl}$ treatment restored long-term neurocognitive function in experimental cerebral malaria. Thus, increased IL-10 production in the brain as a consequence of GSK3 $\beta$ inhibition could have helped restore neurocognitive impairment in the above findings in experimental cerebral malaria.

The cytokine-modulatory effect of quercetin reported renders it different from the conventional anti-malarial agents, which in most cases, only exhibit anti-parasitic activity. There is an urgent need for new therapeutic approaches for malaria to mitigate the cytokine storm during the early infection phase instead of only focusing on eliminating the parasite. Inhibitors of GSK $3 \beta$ has the potential to simultaneously target both parasite growth and overwhelming immune response against $P$. falciparum. 


\section{Materials and Methods}

\subsection{Parasites}

The human malarial parasite, P. falciparum 3D7 (chloroquine-sensitive) (MRA-102) and the rodent malarial parasites, P. berghei NK65 (MRA-268) and P. berghei ANKA (MRA-671), were originally obtained from BEI Resources, NIAID, NIH (P. falciparum, Strain 3D7, MRA102, contributed by Daniel J. Carucci; P. berghei, Strain NK65, MRA-268, contributed by Victor Nussenzweig; P. berghei, Strain ANKA, MRA-671, contributed by M. F. Wiser).

\subsection{In Vitro Anti-Plasmodial Assessment}

P. falciparum 3D7 was cultured in Roswell Park Memorial Institute-1640 (RPMI-1640) culture medium in the asynchronised phase at $2 \%$ haematocrit and $2 \%$ parasitaemia in $100 \mu \mathrm{L}$ of quercetin at concentrations ranging from 0.0001 to $100 \mu \mathrm{M}$. Parasitised red blood cells without treatment served as the positive control. As a negative control, un-parasitised $\mathrm{O}+$ red blood cells with no treatment were used in the assay. The concentration of the test compound used in the study ranged from 0.0001 to $1000 \mu \mathrm{g} / \mathrm{mL}$. The anti-malarial reference drug CQ used ranged from 0.0001 to $10 \mu \mathrm{M}$. The assay was based on the lactate dehydrogenase enzymatic reaction (pLDH) [62,63]. After $48 \mathrm{~h}$ incubation of P. falciparum cultures with test compounds, Malstat and NBT/PES reagents were added to allow colour changes. Absorbance readings were taken at $650 \mathrm{~nm}$ using a spectrophotometer (Fluorostar OPTIMA, Ortenberg, Germany). Data were analysed for $\mathrm{IC}_{50}$ values (inhibition concentration at $50 \%$ parasite growth) through non-linear regression.

\subsection{In Vitro Cytotoxicity Assessment}

Chang liver cells were purchased from the American Type Culture Collection (ATCC Manassas, VA), USA. Cytotoxicity of quercetin was measured using the 3-(4, 5-dimethylthiazol2-yl)-2, 5-diphenyltetrazolium bromide (MTT) assay [64,65]. Chang liver cells were seeded at $2 \times 10^{4}$ in Dulbecco's Modified Eagle Medium (DMEM). The concentration of the test compound used in the assay ranged from 0.0001 to $1000 \mathrm{mg} / \mathrm{mL}$. Cell suspension without test compound was set as positive control. The culture was incubated with or without test compound for $48 \mathrm{~h}\left(37^{\circ} \mathrm{C}, 5 \% \mathrm{CO}_{2}\right)$. Then, MTT-PBS reagent was aliquoted into each well. The plates were incubated for $3 \mathrm{~h}$ at $37^{\circ} \mathrm{C}$. The mixture was removed and replaced with dimethyl sulphoxide (DMSO) to dissolve the MTT formazan product. The mixture was mixed for $15 \mathrm{~min}$, and absorbance measured at $540 \mathrm{~nm}$ (Fluorostar OPTIMA). IC 50 values were calculated through a non-linear regression curve. Selectivity index (SI) values were calculated based on the following formula: $\mathrm{SI}=\left(\mathrm{IC}_{50} \mathrm{MTT}\right.$ assay $) /\left(\mathrm{IC}_{50} \mathrm{pLDH}\right.$ assay $)$.

\subsection{Experimental Animals}

Male ICR mice weighing 20-25 g provided by the Animal House Complex, Universiti Kebangsaan Malaysia (UKM) were used. Permission and approval for animal studies were obtained from the Universiti Kebangsaan Malaysia Animal Ethics Committee (UKMAEC) (reference number: FST/2015/HASIDAH/11-FEB./640-FEB.-2015-DEC.-2016).

\subsection{Survivability Test}

In order to ensure that the dosage of quercetin (Sigma, St. Louis, MO, USA) used in the four-day suppressive test did not impact survival and toxicity of the experimental animals, survivability and behavioural changes were monitored. A total of 49 healthy male ICR mice $(n=7)$ were injected (intraperitoneal (i.p.)) with 2.5, 5, 10, 15, 25, and $50 \mathrm{mg} / \mathrm{kg}$ body weight (BW) quercetin daily for four consecutive days. Quercetin was freshly prepared by first dissolving $50 \mathrm{mg}$ with $1 \mathrm{~mL}$ of DMSO (Sigma, St. Louis, MO, USA) then diluting it to the desired concentrations using normal saline $(0.85 \%(w / v) \mathrm{NaCl}$ solution). The final percentage of DMSO in the solution did not exceed $10 \%$ to ensure no toxic and harmful effect to the animals. Each mouse was administered with quercetin in $0.2 \mathrm{~mL}$ injection volume. $\mathrm{NaCl}$ solution $(0.85 \%(w / v))$ was administered to the control group of animals. Gross behavioural changes (e.g., diarrhoea, excess urination, lethargy, or 
reduction in locomotor activities) and survivability of all groups were monitored within 30 days.

\subsection{Four-Day Suppressive Test}

The anti-malarial activity of quercetin was assessed in male ICR mice according to the four-day suppressive test [66,67]. Mice were randomly divided into eight groups $(n=7)$ for P. berghei NK65 infection. Each mouse was inoculated i.p. with $0.2 \mathrm{~mL}$ of $2 \times 10^{7}$ of pRBC (parasitised red blood cells) containing $P$. berghei NK65. The animals infected with NK65 strain were administered i.p. with $2.5,5,10,25$, and $50 \mathrm{mg} / \mathrm{kg} \mathrm{BW/day} \mathrm{quercetin.} \mathrm{In} \mathrm{a}$ separate experiment, animals were randomly divided into six groups $(n=7)$ for $P$. berghei ANKA infection. Each mouse was inoculated i.p. with $0.2 \mathrm{~mL}$ of $2 \times 10^{7}$ of pRBC containing P. berghei ANKA. The animals infected with ANKA strain were then administered i.p. with 15,25 , and $50 \mathrm{mg} / \mathrm{kg} B W /$ day quercetin. For both infections, CQ at $10 \mathrm{mg} / \mathrm{kg} \mathrm{BW} /$ day was used as anti-malarial reference drug (positive control), $\mathrm{LiCl}$ at $100 \mathrm{mg} / \mathrm{kg} \mathrm{BW/day}$ as GSK3 inhibitor reference drug, and an injection of $0.2 \mathrm{~mL}$ of $0.85 \%(w / v) \mathrm{NaCl}$ to the infected animals as non-treated controls (negative control). Mice were administered with test compounds for four consecutive days, starting at one hour after parasite inoculation on day 0 (D0). Thin blood smears were prepared at day 4 (D4) from tail blood of infected mice. The percentage of chemo-suppression (PC) (\%) was then determined by using the following formula:

$$
\mathrm{PC}=100 \times[(\mathrm{A}-\mathrm{B})] / \mathrm{A}
$$

where A represents the percentage of parasitaemia (\%) of non-treated negative control and $\mathrm{B}$ represents the percentage of parasitaemia (\%) in test groups.

\subsection{Western-Blotting Analysis}

On day 4 (D4) post-infection, P. berghei NK65-infected mice were sacrificed for liver collection, while P. berghei ANKA-infected animals were sacrificed for the brain. Each organ was rinsed with ice-cold pH 7.2 PBS solution and dried on $3 \mathrm{~mm}$ Whatman paper. The organs were homogenised on ice with cold extraction buffer (RIPA buffer $(150 \mathrm{mM} \mathrm{NaCl}$, $1 \%$ Triton X-100 (v/v), $0.5 \%$ sodium deoxycholate $(w / v), 0.1 \%$ SDS $(w / v), 50 \mathrm{mM}$ Tris- $\mathrm{HCl}$ $\mathrm{pH}$ 8.0, and $1 \mathrm{mM}$ EGTA)) and phosphatase inhibitor (15 mM NaF, $1 \mathrm{mM} \mathrm{Na}_{3} \mathrm{VO}_{4}$, and 5 $\mathrm{mM}$ EDTA). Samples were then centrifuged at $12,000 \times \mathrm{g}$ for $30 \mathrm{~min}$ at $4{ }^{\circ} \mathrm{C}$ (Eppendorf, Model 5810R, Hamburg, Germany). Total protein in the organ extracts were determined using the Bradford method [68].

Protein separation was done using sodium dodecyl sulfate polyacrylamide gel electrophoresis (SDS-PAGE) [69]. Equal amounts of liver protein samples $(40 \mu \mathrm{g})$ were loaded into each well of SDS-PAGE gels (30\% acrylamide). The separated proteins on the gel were then transferred onto nitrocellulose membrane Hybond ECL (GE Healthcare, Amersham, UK). The membrane was incubated with primary monoclonal antibodies, anti-GSK3 $\beta$, antiphosphoSer9-GSK3 $\beta$ or $\beta$-actin (Cell Signaling Technology, Beverly, MA, USA) followed by a 2 -h incubation with corresponding secondary antibody, anti-rabbit IgG HRP-linked antibody (Cell Signaling Technology, Beverly, MA, USA) at room temperature. Detection of immunoreactive proteins was carried out using enhanced chemiluminescence reagent (ECL) (Thermo Scientific, Waltham, MA, USA) in the dark. Band-area-intensity quantification was performed using a densitometer (Vilber Lourmat, Marne-la-Vallée, France).

\subsection{Serum Cytokine Analysis}

For groups of animals infected with P. berghei NK65 and controls, serum cytokine levels were assessed. At day four post-infection, blood was collected using cardiac puncture from euthanised animals $(n=7)$ and immediately centrifuged to obtain serum. Levels of pro-inflammatory cytokines (TNF- $\alpha$ and IFN- $\gamma$ ) and anti-inflammatory cytokines (IL-10 and IL-4) were measured in sera of treated and control animals using an enzyme-linked immunosorbent assay (ELISA) (QIAGEN, Hilden, Germany). 


\subsection{Statistical Analysis}

Variance analysis and log-rank test (for Kaplan-Meier survival analysis) were conducted to assess the statistical significance of the data between groups. Data obtained are expressed as mean \pm standard deviation (SD). A P value of $<0.05$ between groups was considered to be significant.

\section{Conclusions}

Findings from our study demonstrate that quercetin can elicit anti-malarial and GSK3 $\beta$-mediated cytokine-modulating effects. The dual anti-plasmodial and GSK3 $\beta$ mediated cytokine-modulating activities of quercetin are requisite of its potential as a plant-derived therapeutic in malaria. Quercetin and its derivatives are plausible compounds to be tested in clinical trials. Our findings also reiterate that GSK3 $\beta$ is a plausible anti-malarial target for adjunctive therapy.

Author Contributions: Conceptualisation, A.H.A., S.S., N.S.-J., W.R.M.H., R.B., N.E., H.M.S., H.K.A., and J.L.; methodology, A.H.A., S.S., W.R.M.H., R.B., N.E., and H.M.S.; investigation, A.H.A., S.S., N.S.-J., and W.R.M.H.; data curation, R.B., N.E., and H.M.S.; writing-original draft preparation, A.H.A., S.S., and N.S.-J.; writing-review and editing, A.H.A., S.S., N.E., and H.M.S.; supervision, R.B., N.E., and H.M.S.; funding acquisition, H.K.A. and J.L. All authors have read and agreed to the published version of the manuscript.

Funding: This research was funded by Universiti Kebangsaan Malaysia (GUP-2019-039) and Ministry of Science, Technology and Innovation, Malaysia (02-01-02-SF1248).

Institutional Review Board Statement: Permission and approval for animal studies were obtained from the Universiti Kebangsaan Malaysia Animal Ethics Committee (UKMAEC) (reference number: FST/2015/HASIDAH/11-FEB./640-FEB.-2015-DEC.-2016).

Informed Consent Statement: Not applicable.

Data Availability Statement: The data presented in this study are available in this article.

Acknowledgments: The authors thank staffs from Animal House Complex and University Health Centre, Universiti Kebangsaan Malaysia in critical technical assistance throughout this study.

Conflicts of Interest: The authors declare no conflict of interest.

\section{References}

1. Tisoncik, J.R.; Korth, M.J.; Simmons, C.P.; Farrar, J.; Martin, T.R.; Katze, M.G. Into the eye of the cytokine storm. Microbiol. Mol. Biol. Rev. 2012, 76, 16-32. [CrossRef]

2. Zumla, A.; Rao, M.; Wallis, R.S.; Kaufmann, S.H.E.; Rustomjee, R.; Mwaba, P.; Vilaplana, C.; Yeboah-Manu, D.; Chakaya, J.; Ippolito, G.; et al. Host-directed therapies for infectious diseases: Current status, recent progress, and future prospects. Lancet Infect. Dis. 2016, 16, e47-e63. [CrossRef]

3. Deroost, K.; Pham, T.T.; Opdenakker, G.; Van den Steen, P.E. The immunological balance between host and parasite in malaria. FEMS Microbiol. Rev. 2016, 40, 208-257. [CrossRef] [PubMed]

4. Grau, G.E.; Fajardo, L.F.; Piguet, P.F.; Allet, B.; Lambert, P.H.; Vassalli, P. Tumor necrosis factor (cachectin) as an essential mediator in murine cerebral malaria. Science 1987, 237, 1210-1212. [CrossRef] [PubMed]

5. Haldar, K.; Mohandas, N. Malaria, erythrocytic infection, and anemia. Hematology 2009, 2009, 87-93. [CrossRef] [PubMed]

6. Adderley, J.D.; von Freyend, S.J.; Jackson, S.A.; Bird, M.J.; Burns, A.L.; Anar, B.; Metcalf, T.; Semblat, J.P.; Billker, O.; Wilson, D.W.; et al. Analysis of erythrocyte signalling pathways during Plasmodium falciparum infection identifies targets for host-directed antimalarial intervention. Nat. Commun. 2020, 11, 1-13. [CrossRef] [PubMed]

7. Jantan, I.; Ahmad, W.; Bukhari, S.N.A. Plant-derived immunomodulators: An insight on their preclinical evaluation and clinical trials. Front. Plant Sci. 2015, 6, 655. [CrossRef] [PubMed]

8. Carullo, G.; Cappello, A.R.; Frattaruolo, L.; Badolato, M.; Armentano, B.; Aiello, F. Quercetin and derivatives: Useful tools in inflammation and pain management. Future Med. Chem. 2017, 9, 79-93. [CrossRef] [PubMed]

9. De Feo, M.; Paladini, A.; Ferri, C.; Carducci, A.; Del Pinto, R.; Varrassi, G.; Grassi, D. Anti-Inflammatory and Anti-Nociceptive Effects of Cocoa: A Review on Future Perspectives in Treatment of Pain. Pain Ther. 2020, 9, 231-240. [CrossRef] [PubMed]

10. Kashyap, D.; Sharma, A.; Tuli, H.S.; Sak, K.; Punia, S.; Mukherjee, T.K. Kaempferol-A dietary anticancer molecule with multiple mechanisms of action: Recent trends and advancements. J. Funct. Foods 2017, 30, 203-219. [CrossRef] [PubMed] 
11. Russo, M.; Moccia, S.; Spagnuolo, C.; Tedesco, I.; Russo, G.L. Roles of flavonoids against coronavirus infection. Chem. Biol. Interact. 2020, 328, 109211. [CrossRef]

12. Hämäläinen, M.; Nieminen, R.; Vuorela, P.; Heinonen, M.; Moilanen, E. Anti-inflammatory effects of flavonoids: Genistein, kaempferol, quercetin, and daidzein inhibit STAT-1 and NF-kB activations, whereas flavone, isorhamnetin, naringenin, and pelargonidin inhibit only NF- $\mathrm{BB}$ activation along with their inhibitory effect on iNOS expression and NO production in activated macrophages. Mediat. Inflamm. 2007, 2007, 45673.

13. Yardim, A.; Kandemir, F.M.; Ozdemir, S.; Kucukler, S.; Comakli, S.; Gur, C.; Celik, H. Quercetin provides protection against the peripheral nerve damage caused by vincristine in rats by suppressing caspase 3, NF- $\mathrm{kB}$, ATF-6 pathways and activating Nrf2, Akt pathways. Neurotoxicology 2020, 81, 137-146. [CrossRef] [PubMed]

14. Tang, J.; Diao, P.; Shu, X.; Li, L.; Xiong, L. Quercetin and quercitrin attenuates the inflammatory response and oxidative stress in LPS-induced RAW264.7 cells: In vitro assessment and a theoretical model. BioMed Res. Int. 2019, 2019, 7039802. [CrossRef]

15. Heimfarth, L.; Serafini, M.R.; Martins-Filho, P.R.S.; Quintans, J.S.S.; Júnior, L.J.Q. Drug repurposing and cytokine management in response to COVID-19: A review. Int. Immunopharmacol. 2020, 88, 106947. [CrossRef] [PubMed]

16. Ye, Q.; Wang, B.; Mao, J. The pathogenesis and treatment of the Cytokine Storm'in COVID-19. J. Infect. 2020, 80, 607-613. [CrossRef]

17. Rudd, C.E. GSK-3 inhibition as a therapeutic approach against SARs CoV2: Dual benefit of inhibiting viral replication while potentiating the immune response. Front. Immunol. 2020, 11, 1638-1648. [CrossRef]

18. Wu, W.; Li, R.; Li, X.; He, J.; Jiang, S.; Liu, S.; Yang, J. Quercetin as an antiviral agent inhibits influenza A virus (IAV) entry. Viruses 2016, 8, 6. [CrossRef] [PubMed]

19. Kinker, B.; Comstock, A.T.; Sajjan, U.S. Quercetin: A promising treatment for the common cold. J. Anc. Dis. Prev. Remedies 2014, 2, 1-3. [CrossRef]

20. Johnson, J.L.; Rupasinghe, S.G.; Stefani, F.; Schuler, M.A.; Gonzalez de Mejia, E. Citrus flavonoids luteolin, apigenin, and quercetin inhibit glycogen synthase kinase- $3 \beta$ enzymatic activity by lowering the interaction energy within the binding cavity. J. Med. Food 2011, 14, 325-333. [CrossRef] [PubMed]

21. Sivaraman, D.; Panneerselvam, P. Screening of potential glycogen synthase kinase- $3 \beta$ inhibitors from herbal Lead by in silico docking technique. Int. J. Chem. Tech. Res. 2015, 8, 834-842.

22. Jung, Y.; Shin, S.Y.; Lee, Y.H.; Lim, Y. Flavones with inhibitory effects on glycogen synthase kinase 3ß. Appl. Biol. Chem. 2017, 60, 227-232. [CrossRef]

23. Friday, A.J.; Ikpeazu, V.O.; Otuokere, I.; Igwe, K.K. Targeting Glycogen Synthase Kinase-3 (GSK3 $\beta$ ) With Naturally Occurring Phytochemicals (Quercetin and its Modelled Analogue): A Pharmacophore Modelling and Molecular Docking Approach. Commun. Phys. Sci. 2020, 5, 497-508.

24. Kim, Y.J.; Park, W. Anti-inflammatory effect of quercetin on RAW 264.7 mouse macrophages induced with polyinosinicpolycytidylic acid. Molecules 2016, 21, 450. [CrossRef]

25. Salehi, B.; Machin, L.; Monzote, L.; Sharifi-Rad, J.; Ezzat, S.M.; Salem, M.A.; Merghany, R.M.; El Mahdy, N.M.; Kılıç, C.S.; Sytar, O.; et al. Therapeutic Potential of Quercetin: New Insights and Perspectives for Human Health. ACS Omega 2020, 5, 11849-11872. [CrossRef] [PubMed]

26. Kayano, A.C.A.; Lopes, S.C.; Bueno, F.G.; Cabral, E.C.; Souza-Neiras, W.C.; Yamauchi, L.M.; Foglio, M.A.; Eberlin, M.N.; Mello, J.C.P.; Costa, F.T. In vitro and in vivo assessment of the anti-malarial activity of Caesalpinia pluviosa. Malar. J. 2011, 10, 112-123. [CrossRef] [PubMed]

27. Ganesh, D.; Fuehrer, H.P.; Starzengruber, P.; Swoboda, P.; Khan, W.A.; Reismann, J.A.; Mueller, M.S.; Chiba, P.; Noedl, H. Anti-plasmodial activity of flavonol quercetin and its analogues in Plasmodium falciparum: Evidence from clinical isolates in Bangladesh and standardized parasite clones. Parasitol. Res. 2012, 110, 2289-2295. [CrossRef] [PubMed]

28. Penna-Coutinho, J.; Aguiar, A.C. Commercial drugs containing flavonoids are active in mice with malaria and in vitro against chloroquine-resistant Plasmodium falciparum. Mem. Inst. Oswaldo Cruz 2018, 113, e180279. [CrossRef] [PubMed]

29. Mishra, S.K.; Singh, P.; Rath, S.K. Protective effect of quercetin on chloroquine-induced oxidative stress and hepatotoxicity in mice. Malar. Res. Treat. 2013, 2013, 141734.

30. Embi, N.; Rylatt, D.B.; Cohen, P. Glycogen synthase kinase-3 from rabbit skeletal muscle. Separation from cyclic-AMP-dependent protein kinase and phosphorylase kinase. Eur. J. Biochem. 1980, 107, 519-527. [CrossRef]

31. Wang, H.; Brown, J.; Martin, M. Glycogen synthase kinase 3: A point of convergence for the host inflammatory response. Cytokine 2011, 53, 130-140. [CrossRef]

32. Hoffmeister, L.; Diekmann, M.; Brand, K.; Huber, R. GSK3: A Kinase Balancing Promotion and Resolution of Inflammation. Cells 2020, 9, 820. [CrossRef]

33. Saraswati, A.P.; Ali-Hussaini, S.M.; Krishna, N.H.; Babu, B.N.; Kamal, A. Glycogen synthase kinase-3 and its inhibitors: Potential target for various therapeutic conditions. Eur. J. Med. Chem. 2018, 144, 843-858. [CrossRef] [PubMed]

34. Eldar-Finkelman, H. Glycogen synthase kinase 3: An emerging therapeutic target. Trends Mol. Med. 2002, 8, 126-132. [CrossRef]

35. Takahashi-Yanaga, F. Activator or inhibitor? GSK-3 as a new drug target. Biochem. Pharmacol. 2013, 86, 191-199. [CrossRef]

36. Haque, A.; Best, S.E.; Amante, F.H.; Ammerdorffer, A.; de Labastida, F.; Pereira, T.; Ramm, G.A.; Engwerda, C.R. High parasite burdens cause liver damage in mice following Plasmodium berghei ANKA infection independently of CD8(+) T cell-mediated immune pathology. Infect. Immun. 2011, 79, 1882-1888. [CrossRef] 
37. Mizobuchi, H.; Fujii, W.; Isokawa, S.; Ishizuka, K.; Wang, Y.; Watanabe, S.; Sanjoba, C.; Matsumoto, Y.; Goto, Y. Exacerbation of hepatic injury during rodent malaria by myeloid-related protein 14. PLoS ONE 2018, 13, e0199111. [CrossRef]

38. Dolabela, M.F.; Oliveira, S.G.; Nascimento, J.M.; Peres, J.M.; Wagner, H.; Póvoa, M.M.; de Oliveira, A.B. In vitro anti-plasmodial activity of extract and constituents from Esenbeckia febrifuga, a plant traditionally used to treat malaria in the Brazilian Amazon. Phytomedicine 2008, 15, 367-372. [CrossRef]

39. Hodges, R.E.; Minich, D.M. Modulation of metabolic detoxification pathways using foods and food-derived components: A scientific review with clinical application. J. Nutr. Metab. 2015, 2015, 760689. [CrossRef] [PubMed]

40. Baptista, F.G.; Pamplona, A.; Pena, A.C.; Mota, M.M.; Pied, S.; Vigário, A.M. Accumulation of Plasmodium berghei-infected red blood cells in the brain is crucial for the development of cerebral malaria in mice. Infect. Immun. 2010, 78, 4033-4039. [CrossRef] [PubMed]

41. Ngo-Thanh, H.; Sasaki, T.; Suzue, K.; Yokoo, H.; Isoda, K.; Kamitani, W.; Shimokawa, C.; Hisaeda, H.; Imai, T. Blood-cerebrospinal fluid barrier: Another site disrupted during experimental cerebral malaria caused by Plasmodium berghei ANKA. Int. J. Parasitol. 2020, 50, 1167-1175. [CrossRef]

42. Plantone, D.; Koudriavtseva, T. Current and future use of chloroquine and hydroxychloroquine in infectious, immune, neoplastic, and neurological diseases: A mini-review. Clin. Drug Investig. 2018, 38, 653-671. [CrossRef] [PubMed]

43. Thomé, R.; Lopes, S.C.P.; Costa, F.T.M.; Verinaud, L. Chloroquine: Modes of action of an undervalued drug. Immunol. Lett. 2013, 153, 50-57. [CrossRef]

44. Helgren, T.R.; Sciotti, R.J.; Lee, P.; Duffy, S.; Avery, V.M.; Igbinoba, O.; Akoto, M.; Hagen, T.J. The synthesis, antimalarial activity and CoMFA analysis of novel aminoalkylated quercetin analogs. Bioorg. Med. Chem. Lett. 2015, 25, 327-332. [CrossRef]

45. Hassan, W.R.M.; Basir, R.; Ali, A.H.; Embi, N.; Sidek, H.M. Anti-malarial and cytokine-modulating effects of andrographolide in a murine model of malarial infection. Trop. Biomed. 2019, 36, 776-791.

46. Beurel, E.; Grieco, S.F.; Jope, R.S. Glycogen synthase kinase-3 (GSK3): Regulation, actions, and diseases. Pharmacol. Ther. 2015, 148, 114-131. [CrossRef] [PubMed]

47. Cichocki, F.; Valamehr, B.; Bjordahl, R.; Zhang, B.; Rezner, B.; Rogers, P.; Gaidarova, S.; Moreno, S.; Tuininga, K.; Dougherty, P.; et al. GSK3 inhibition drives maturation of NK cells and enhances their antitumor activity. Cancer Res. 2017, 77, 5664-5675. [CrossRef]

48. Wong, S.K.; Jann, M.L.S.; Sudi, S.; Hasan, M.; Chin, L.P.; Embi, N.; Sidek, H.M. Anti-malarial and anti-inflammatory effects of Gynura procumbens are mediated by kaempferol via inhibition of glycogen synthase kinase-3 $\beta$ (GSK3 $\beta$ ). Sains Malays. 2015, 44, 1489-1500.

49. Somsak, V.; Nakinchat, S. Anti-malarial and anti-hypoglycemic effects of Moringa oleifera leaf Extraction Plasmodium berghei infection in mice. Asian J. Pharm. 2017, 1, 12-17.

50. Ounjaijean, S.; Benjasak, N.; Sae-Lao, S.; Somsak, V. Kaempferol Addition Increases the Anti-malarial Activity of Artesunate in Experimental Mice. J. Trop. Med. 2020, 2020, 6165928. [CrossRef]

51. Costa, L.G.; Garrick, J.M.; Roquè, P.J.; Pellacani, C. Mechanisms of Neuroprotection by Quercetin: Counteracting Oxidative Stress and More. Oxid. Med. Cell. Longev. 2016, 2016, 2986796. [CrossRef]

52. Yang, Z.H.; Sun, X.; Mei, C.; Sun, X.B.; Liu, X.D.; Chang, Q. An in vitro transport model for rapid screening and predicting the permeability of candidate compounds at blood-brain barrier. J. Asian Nat. Prod. Res. 2011, 13, 1087-1097. [CrossRef]

53. Kitagishi, Y.; Nakanishi, A.; Ogura, Y.; Matsuda, S. Dietary regulation of PI3K/AKT/GSK-3 $\beta$ pathway in Alzheimer's disease. Alzheimer Res. Ther. 2014, 6, 35-45. [CrossRef] [PubMed]

54. Zhang, X.; Jiang, W.; Zhou, A.L.; Zhao, M.; Jiang, D.R. Inhibitory effect of oxymatrine on hepatocyte apoptosis via TLR4/PI3K/Akt/GSK-3ß signaling pathway. World J. Gastroenterol. 2017, 23, 3839-3849. [CrossRef]

55. Zhang, F.; Phiel, C.J.; Spece, L.; Gurvich, N.; Klein, P.S. Inhibitory phosphorylation of glycogen synthase kinase-3 (GSK-3) in response to lithium: Evidence for autoregulation of GSK-3. J. Biol. Chem. 2003, 278, 33067-33077. [CrossRef] [PubMed]

56. Zakaria, N.A.; Noor, E.; Hasidah, M.S. Suppression of Plasmodium berghei parasitemia by $\mathrm{LiCl}$ in an animal infection model. Trop Biomed. 2010, 27, 624-631.

57. Dai, M.; Freeman, B.; Shikani, H.J.; Bruno, F.P.; Collado, J.E.; Macias, R.; Reznik, S.E.; Davies, P.; Spray, D.C.; Tanowitz, H.B.; et al. Altered Regulation of Akt Signaling with Murine Cerebral Malaria, Effects on Long-Term Neuro-Cognitive Function, Restoration with Lithium Treatment. PLoS ONE 2012, 7, e44117. [CrossRef] [PubMed]

58. Coban, C. The host targeting effect of chloroquine in malaria. Curr. Opin. Immunol. 2020, 66, 98-107. [CrossRef]

59. De Oca, M.M.; Kumar, R.; de Labastida Rivera, F.; Amante, F.H.; Sheel, M.; Faleiro, R.J.; Bunn, P.T.; Best, S.E.; Beattie, L.; Ng, S.S.; et al. Type I interferons regulate immune responses in humans with blood-stage Plasmodium falciparum infection. Cell Rep. 2016, 17, 399-412.

60. Varo, R.; Crowley, V.M.; Sitoe, A.; Madrid, L.; Serghides, L.; Kain, K.C.; Bassat, Q. Adjunctive therapy for severe malaria: A review and critical appraisal. Malar. J. 2018, 17, 1-18. [CrossRef]

61. Worthen, R.J.; Zighelboim, S.S.G.; Jaramillo, C.S.T.; Beurel, E. Anti-inflammatory IL-10 administration rescues depressionassociated learning and memory deficits in mice. J. Neuroinflamm. 2020, 17, 1-16. [CrossRef]

62. Makler, M.T.; Ries, J.M.; Williams, J.A.; Bancroft, J.E.; Piper, R.C.; Gibbins, B.L.; Hinrichs, D.J. Parasite lactate dehydrogenase as an assay for Plasmodium falciparum drug sensitivity. Am. J. Trop. Med. Hyg. 1993, 48, 739-741. [CrossRef] 
63. Ali, A.H.; Agustar, H.K.; Hassan, N.I.; Latip, J.; Embi, N.; Sidek, H.M. Data on antiplasmodial and stage-specific inhibitory effects of Aromatic (Ar)-Turmerone against Plasmodium falciparum 3D7. Data Brief. 2020, 33, 106592. [CrossRef]

64. Mosmann, T. Rapid colorimetric assay for cellular growth and survival: Application to proliferation and cytotoxicity assays. $J$. Immunol. Methods 1983, 65, 55-63. [CrossRef]

65. Dahari, D.E.; Salleh, R.M.; Mahmud, F.; Chin, L.P.; Embi, N.; Sidek, H.M. Anti-malarial activities of two soil actinomycete isolates from sabah via inhibition of glycogen synthase kinase 3ß. Trop. Life Sci. Res. 2016, 27, 53. [CrossRef]

66. Peters, W.; Portus, J.H.; Robinson, B.L. The chemotherapy of rodent malaria, XXII: The value of drug-resistant strains of $P$. berghei in screening for blood schizontocidal activity. Ann. Trop. Med. Parasitol. 1975, 69, 155-171. [CrossRef]

67. Ali, A.H.; Sudi, S.; Basir, R.; Embi, N.; Sidek, H.M. The Antimalarial Effect of Curcumin Is Mediated by the Inhibition of Glycogen Synthase Kinase-3 $\beta$. J. Med. Food 2017, 20, 152-161. [CrossRef] [PubMed]

68. Bradford, M.M. A rapid and sensitive method for the quantitation of microgram quantities of protein utilizing the principle of protein-dye binding. Anal. Biochem. 1976, 72, 248-254. [CrossRef]

69. Schägger, H.; Von Jagow, G. Tricine-sodium dodecyl sulfate-polyacrylamide gel electrophoresis for the separation of proteins in the range from 1 to $100 \mathrm{kDa}$. Anal. Biochem. 1987, 166, 368-379. [CrossRef] 